\title{
The effect of selected PGPB bacteria on yield and health of lettuce and cucumber in field cultivation
}

\author{
Wpływ wybranych bakterii PGPB na plonowanie \\ oraz zdrowotność sałaty i ogórka w uprawie polowej
}

\author{
Magdalena Szczech*, Beata Kowalska, Jan Sobolewski
}

\begin{abstract}
Summary
The activity of bacteria B125, PT60 (Enterobacter cloacae) and PZ9 (Bacillus sp.) was examined in field cultivation of lettuce and cucumber. In the experiments with lettuce the mixture of PZ9 + B125 was applied for transplants production by drenching of growing medium with bacterial suspension or mixing with alginate microcapsules. Controls were water or thiram. The best transplants growth was obtained with bacterial suspension. However, after transplanting to field the yield and health of treated lettuce did not differ compared to untreated control. The microcapsules and thiram inhibited growth of young plants and reduced lettuce yield. Thiram increased plant infection by Sclerotinia sclerotiorum. In the experiments with cucumber bacteria PT60 was applied as suspension for plant drenching or in form of microcapsules for seed coating. The microcapsules reduced cucumber germination, but the yield did not differ between treatments. PT60 significantly reduced the symptoms of downy mildew.
\end{abstract}

Key words: lettuce; cucumber; PGPB bacteria; downy mildew

\section{Streszczenie}

Aktywność bakterii B125, PT60 (Enterobacter cloacae) oraz PZ9 (Bacillus sp.) była badana w polowej uprawie sałaty i ogórka. W doświadczeniach z sałatą użyto mieszankę bakterii PZ9 + B125 na etapie produkcji rozsady do podlewania roślin lub $\mathrm{W}$ postaci mikrokapsuł alginianowych dodanych do podłoża. Jako kontrolę stosowano wodę lub tiuram. Najlepszy wzrost rozsady uzyskano po zastosowaniu zawiesiny bakterii. Jednak po przesadzeniu w pole, plon i zdrowotność roślin nie różniły się istotnie w porównaniu do nietraktowanej kontroli. Mikrokapsuły z bakteriami PZ9 i B125 oraz tiuram hamowały wzrost młodych roślin i zmniejszały plon sałaty. Tiuram zwiększał porażenie roślin przez Sclerotinia sclerotiorum. W doświadczeniach z ogórkami bakterie PT60 stosowano jako zawiesinę do podlewania roślin w polu lub w formie mikrokapsuł do zaprawiania nasion. Mikrokapsuły obniżały wschody roślin, ale plony nie różniły się między obiektami. PT60 powodował istotną redukcję nasilenia mączniaka rzekomego na roślinach.

Słowa kluczowe: sałata; ogórek; bakterie PGPB; mączniak rzekomy

\footnotetext{
Instytut Ogrodnictwa

Konstytucji 3 Maja 1/3, 96-100 Skierniewice

*corresponding author: magdalena.szczech@inhort.pl
} 


\section{Wstęp / Introduction}

W trosce o ochronę środowiska promowany jest integrowany system uprawy, w którym ważnym elementem jest m.in. stosowanie zabiegów optymalizujących wzrost roślin, a także zapobieganie rozprzestrzenianiu organizmów patogenicznych przy użyciu metod alternatywnych wobec stosowanych obecnie na szeroką skalę produktów syntetycznych. Jedną $\mathrm{z}$ koncepcji jest wykorzystanie mikroorganizmów, które naturalnie zasiedlają środowisko glebowe, a szczególnie strefę korzeniową roślin. Ich korzystne działanie na rośliny jest znane już od końca 19. wieku, kiedy odkryto bakterie $\mathrm{z}$ rodzaju Rhizobium (Hellriegel i Wilfarth 1888). Od tego czasu prowadzone są intensywne badania nad wzajemnymi relacjami pomiędzy roślinami i mikroorganizmami. Stwierdzono, że liczne gatunki bakterii, nazwane $\mathrm{z}$ angielskiego ,plant growth-promoting bacteria" - PGPB, wspomagają wzrost roślin, a także mogą je chronić przed stresowymi czynnikami fizycznymi, chemicznymi i biologicznymi, jakimi są organizmy patogeniczne (Bhattacharyya i Jha 2012; Ruzzi i Aroca 2015). Bezpośrednie działanie bakterii na roślinę polega m.in. na dostarczaniu składników pokarmowych, syntezie fitohormonów stymulujących rozwój systemu korzeniowego i części nadziemnych, czy redukcji poziomu etylenu niekorzystnie wpływającego na ukorzenianie się roślin (Ali i wsp. 2015; Verbon i Liberman 2016). Pośredni sposób działania tych mikroorganizmów polega na ochronie roślin przed skutkami aktywności patogenów. Obecnie wiele szczepów zostało wprowadzonych na rynek jako bionawozy, biostymulatory lub biologiczne środki ochrony roślin (Bhattacharyya i Jha 2012; Bishnoi 2015). Rynek dla tego typu preparatów powiększa się. Jednak, w dalszym ciągu problemem jest wrażliwość mikroorganizmów i zależność od warunków środowiska, rodzaju gleby czy gatunku rośliny. Według Howella (2003) najlepszą metodą uzyskania skutecznych szczepów aktywnych mikroorganizmów jest ich pozyskiwanie z obszarów, gdzie przewiduje się je stosować. Dlatego wydaje się zasadne opracowywanie preparatów na bazie mikroorganizmów przystosowanych do warunków i systemów uprawy na określonych obszarach. Ważny jest też wybór najbardziej efektywnej metody aplikacji.

W Instytucie Ogrodnictwa w Skierniewicach wyselekcjonowano kilka szczepów bakterii wpływających korzystnie na wzrost i zdrowotność roślin warzywnych, m.in. szczepy bakterii B125 i PT60 (Enterobacter cloacae) oraz szczep PZ9 (Bacillus sp). Pozytywne działanie tych bakterii potwierdzono w doświadczeniach laboratoryjnych, kontenerowych i szklarniowych, gdzie wykazywały antagonizm wobec grzybów patogenicznych (Fusarium i Rhizoctonia), stymulowały wzrost roślin pomidora i ogórka, a także poprawiały plonowanie pomidorów w warunkach szklarniowych (Szczech i Dyki 2007; Szczech i Dyśko 2008; Szczech 2009; Szczech i wsp. 2009). Szczep PT60 indukował $\mathrm{w}$ roślinach reakcje wskazujące na pobudzanie mechanizmów odporności (Szczech i Dyki 2007). Skuteczność tych bakterii nie była analizowana w warunkach polowych.

Celem niniejszych badań była ocena możliwości wykorzystania różnych metod aplikacji wymienionych bakterii w polowej uprawie sałaty kruchej oraz ogórków. Sałata należy do roślin o krótkim okresie wegetacji, lecz jest atakowana przez wiele patogenów. Spożywanie sałaty w postaci świeżych liści ogranicza możliwości stosowania chemicznej ochrony. W przypadku ogórka występują problemy ze zwalczaniem mączniaka rzekomego. Włączenie aktywnych mikroorganizmów w system uprawy tych roślin może wpłynąć na ich wzrost i plonowanie.

\section{Materiały i metody / Materials and methods}

Do doświadczeń wykorzystano szczepy bakterii B125 i PT60 (Enterobacter cloacae) oraz PZ9 (Bacillus sp.), pochodzące z kolekcji Pracowni Mikrobiologii Instytutu Ogrodnictwa w Skierniewicach. Bakterie namnażano w bulionie odżywczym $(100 \mathrm{ml})$, w temperaturze $30^{\circ} \mathrm{C}$ przez 48 godzin. Kultury bakterii używano do przygotowywania następujących form inokulacyjnych: zawiesina komórek bakterii (do podlewania roślin), mikrokapsuły alginianowe (do zaprawiania nasion oraz jako dodatek do podłoża). Zawiesiny komórek uzyskiwano odwirowując kultury bakterii i dodając $5 \mathrm{ml} 0,85 \%$ roztworu $\mathrm{NaCl}$ po usunięciu płynu pohodowlanego. W ten sposób otrzymywano zawiesinę wyjściową do produkcji inokulum. Aby przygotować płyn do podlewania roślin, zawiesinę wyjściową rozcieńczano $\mathrm{w}$ wodzie do otrzymania zagęszczenia komórek około $10^{9}-10^{10} \mathrm{jtk} / \mathrm{ml}$. Liczbę bakterii w zawiesinach określano metodą rozcieńczeń za pomocą posiewów na agarze odżywczym.

Mikrokapsuły alginianowe $\mathrm{z}$ bakteriami przygotowywano według zmodyfikowanej metody emulsyfikacji opisanej przez Windera i wsp. (2003) i zmodyfikowanej przez Szczech i Maciorowskiego (2016). 100 ml kultury bakterii B125, PT60 lub PZ9 mieszano z 2 g alginianu sodu i 1 g wysuszonego i wysterylizowanego torfu. Składniki mieszano na mieszadle magnetycznym przez $60 \mathrm{~min}$. Do mieszaniny dodano $100 \mathrm{ml}$ oleju roślinnego i mieszano przez $1 \mathrm{~min}$. do wytworzenia emulsji. Wytworzone w emulsji mikrokapsuły utwardzano dolewając $200 \mathrm{ml} 1 \mathrm{M}$ roztworu chlorku wapnia. Następnie utrwalano je mieszając przez $60 \mathrm{~min}$. Mikrokapsuły oddzielano od fazy ciekłej przez filtrację za pomocą pompy próżniowej i przechowywano w sterylnych pojemnikach w temperaturze $4^{\circ} \mathrm{C}$. Dla każdego szczepu bakterii wykonano po trzy porcje mikrokapsuł. Zagęszczenie bakterii w mikrokapsułach wynosiło około $10^{11} \mathrm{jtk} / \mathrm{g}$.

Doświadczenia polowe $\mathrm{z}$ roślinami sałaty i ogórka przeprowadzono w latach 2012-2015 na polu doświadczalnym Instytutu Ogrodnictwa w Skierniewicach. Uprawę prowadzono na glebie klasy III. Przed wysadzeniem lub wysiewem roślin stosowano tradycyjne uprawki. Glebę nawożono nawozami mineralnymi stosując: $\mathrm{N}-140 \mathrm{~kg} / \mathrm{ha}$, $\mathrm{P}-40 \mathrm{~kg} / \mathrm{ha}$ i $\mathrm{K}-130 \mathrm{~kg} / \mathrm{ha}$. Roślin nie nawożono pogłównie i nie wykonywano żadnych zabiegów ochronnych, natomiast stosowano regularne nawadnianie.

W doświadczeniach z sałatą użyto mieszankę szczepów bakterii B125 i PZ9 na etapie produkcji rozsady. Rozsadę sałaty kruchej odmiany Królowa Lata przygotowywano w szklarni, w wielodoniczkach wypełnionych podłożem Klasmann. Zastosowano następujące warianty inokulacyj- 
ne: (i) podlewanie podłoża zawiesiną komórek bakterii B125 + PZ9; (ii) aplikacja mikrokapsuł z bakteriami B125 + PZ9 do podłoża; (iii) zaprawianie nasion Zaprawą Nasienną T 75 DS/WS (75\% tiuram); (iv) kontrola rośliny podlane wodą. W wariancie pierwszym podłoże podlewano zawiesiną bezpośrednio po wysiewie nasion sałaty i ponownie po dwóch tygodniach. Stosowano dawkę $10 \mathrm{ml}$ zawiesiny na $100 \mathrm{ml}$ podłoża (obj. komory w wielodoniczce). W pozostałych wariantach dodawano po $10 \mathrm{ml}$ wody. Wyjściowe zagęszczenie bakterii po pierwszej aplikacji wynosiło około $10^{8} \mathrm{jtk} / \mathrm{g}$ podłoża. W drugim wariancie mikrokapsuły $z$ bakteriami B125 i PZ9, wymieszane przed użyciem w proporcji wagowej 1:1, dodawano do podłoża $\mathrm{w}$ dawce $0,5 \%$ ww. i dokładnie mieszano. Wyjściowe zagęszczenie bakterii po aplikacji mikrokapsuł wynosiło około $10^{7} \mathrm{jtk} / \mathrm{g}$ podłoża. Inokulowanym podłożem wypełniano wielodoniczki i wysiewano nasiona sałaty. Każdy wariant wykonano w trzech powtórzeniach, po 56 roślin w każdym powtórzeniu. Rozsadę uprawiano w warunkach szklarniowych przez miesiąc. Przed wysadzeniem do gruntu oceniano liczbę siewek uzyskanych w każdym obiekcie oraz wykonywano pomiary świeżej masy części nadziemnych i suchej masy korzeni dla 10 roślin pobranych z każdego obiektu w trzech powtórzeniach. Doświadczenie powtórzono cztery razy.

Rozsadę sałaty wysadzano do gruntu na poletka o powierzchni 4,5 $\mathrm{m}^{2}$ (po 30 roślin na poletko). Każdy wariant wykonano w trzech powtórzeniach. Doświadczenie założono w układzie bloków losowych. Przed zbiorami wykonywano ocenę porażenia wszystkich główek sałaty przez patogeny stosując skalę $0-4$, gdzie: 0 - rośliny bez objawów porażenia, $1-<25 \%$ główki $\mathrm{z}$ objawami porażenia, 2 - od 25 do $50 \%, 3$ - od 50 do $75 \%, 4->75 \%$ główki porażonej. Główną przyczyną porażenia był grzyb Sclerotinia sclerotiorum. Podczas zbiorów oceniano masę całkowitą główki oraz masę i średnicę główki handlowej. Plon przedstawiono $\mathrm{w} \mathrm{kg} / \mathrm{m}^{2}$ powierzchni. Doświadczenie powtórzono czterokrotnie.

W doświadczeniach z ogórkiem użyto szczep bakterii PT60. Nawożenie, zabiegi pielęgnacyjne i nawadnianie wykonywano tak, jak w doświadczeniach z sałatą. Nie stosowano ochrony chemicznej. Nasiona ogórków odmiany Polan $\mathrm{F}_{1}$ wysiewano co $15 \mathrm{~cm}$ w dwóch rzędach, rozmieszczonych w odległości około $80 \mathrm{~cm}$, na poletkach o długości $3 \mathrm{~m}$. Zastosowano następujące warianty inokulacyjne: (i) podlewanie roślin zawiesiną komórek bakterii PT60; (ii) zaprawianie nasion mikrokapsułami z bakteriami PT60; (iii) zaprawianie nasion Zaprawą Nasienną T 75 DS/WS (75\% tiuram); (iv) kontrola - rośliny nietraktowane. Podlewanie zawiesiną komórek PT60 rozpoczęto po wysiewie nasion i powtarzano trzykrotnie w odstępach dwutygodniowych. Na poletko zużywano 41 zawiesiny inokulacyjnej o zagęszczeniu komórek bakterii około $10^{9} \mathrm{jtk} / \mathrm{ml}$. Zaprawianie nasion ogórka mikrokapsułami przebiegało następująco: $10 \mathrm{~g}$ nasion ogórka zwilżano $0,5 \mathrm{ml}$ sterylizowanej wody i dodawano $0,25 \mathrm{~g}$ karboksymetylocelulozy (CMC) oraz 2,5 g mikrokapsuł zawierających bakterie PT60. Po dokładnym wymieszaniu nasiona podsuszano i wysiewano do gleby. Liczebność bakterii na tak przygotowanych nasionach wynosiła około
$10^{8}$ jtk na nasiono. Każdy wariant wykonano w trzech powtórzeniach. Doświadczenie założono w układzie bloków losowych. W trakcie uprawy oceniano wschody ogórków oraz stopień porażenia roślin przez Pseudoperonospora cubensis - sprawcę mączniaka rzekomego. Wykonywano trzy oceny porażenia w odstępach dwóch tygodni. Wstępną ocenę przeprowadzano w momencie wystąpienia pierwszych objawów mączniaka. Porażenie określano według ośmiostopniowej skali 0-7, w której: $1-<1 \%$ liści z objawami porażenia; 2 - od 2 do $6 \%$; $3-$ od 7 do $15 \% ; 4-$ od 16 do $30 \%$; 5 - od 31 do $50 \%$; 6 - od 51 do $80 \% ; 7$ - od 81 do $100 \%$. Zbiory ogórków prowadzono co 2-3 dni. Plon przedstawiono w przeliczeniu na $\mathrm{m}^{2}$ powierzchni. Doświadczenie powtórzono czterokrotnie.

Wyniki opracowano statystycznie za pomocą analizy wariancji w modelu bloków losowych. W przypadku stwierdzenia istotności efektu badanego czynnika szczegółowe porównania średnich wykonano za pomocą procedury Duncana. Wszystkie obliczenia wykonano w programie STATISTICA v. 10.

\section{Wyniki i dyskusja / Results and discussion}

Stosowanie wybranych bakterii w uprawie sałaty kruchej i ogórków gruntowych miało pozytywny wpływ na niektóre parametry rozwoju tych roślin. W uprawie sałaty stosowano mieszankę dwóch szczepów bakterii $E$. cloacae sp. B125 i Bacillus sp. PZ9. Użycie tych bakterii w postaci wodnej zawiesiny do podlewania $\mathrm{w}$ czasie produkcji rozsady sałaty, powodowało istotne zwiększenie wschodów, a także stymulację wzrostu roślin (tab. 1). Aplikacja bakterii $\mathrm{w}$ tej formie miała szczególnie pozytywny wpływ na rozwój systemu korzeniowego sałaty, którego sucha masa wzrastała o ponad $30 \%$ w porównaniu do korzeni roślin kontrolnych. Wcześniejsze badania wykazały, że bakterie B125 stymulowały wzrost rozsady pomidorów, a także podwyższały wschody pomidorów w podłożu skażonym patogenicznym grzybem Rhizoctonia solani (Szczech i Dyki 2007). Szczep B125 wykazywał także pozytywne działanie na wzrost i zdrowotność roślin, gdy był stosowany razem $\mathrm{z}$ innymi bakteriami (Szczech i Dyśko 2008; Szczech 2009). Z kolei PZ9, dodawany do podłoża, istotnie stymulował wzrost sałaty w początkowych fazach rozwoju, a także ograniczał zasiedlenie korzeni ogórków i porażenie roślin pomidora przez grzyby z rodzaju Fusarium (Szczech 2009; Szczech i Maciorowski 2016). Wstępne badania wykazały, że zastosowanie kombinacji tych dwóch szczepów bakterii poprawiało efektywność ich działania. Wyniki uzyskane w prezentowanych badaniach wskazują na możliwość zastosowania mieszanki bakterii B125 i PZ9 do przyspieszania i stymulacji wzrostu roślin w produkcji rozsady. W tym przypadku konieczne jest jednak dalsze dopracowanie formy aplikacyjnej, gdyż użycie zawiesiny świeżych kultur bakterii jest trudne w praktyce. Z kolei zastosowane $\mathrm{w}$ badaniach mikrokapsuły alginianowe z bakteriami wykazały niekorzystne działanie dla wzrostu młodych roślin sałaty (tab. 1). Dodawane do podłoża powodowały zahamowanie wzrostu rozsady, co objawiało 
się szczególnie istotnym obniżeniem masy części nadziemnych. Przyczyną tego zjawiska prawdopodobnie mogły być szkodliwe dla roślin mikroorganizmy obecne w podłożu i stymulowane dodatkiem mikrokapsuł. W odrębnym teście, gdzie do podłoża skażonego grzybem zgorzelowym Pythium spp. dodano mikrokapsuły alginianowe, obserwowano znaczące obniżenie wschodów sałaty w porównaniu do skażonego podłoża, ale bez mikrokapsuł. Wyniki analizy mikrobiologicznej tych podłoży wykazały zwiększenie liczebności Pythium spp. w wariancie z mikrokapsułami. Również Szczech i Maciorowski (2016) obserwowali wzrost liczebności Fusarium oxysporum f. sp. lycopersici po dodaniu mikrokapsuł alginianowych do podłoża skażonego tym grzybem. Kapsułkowanie przy użyciu alginianu sodu jest jedną $\mathrm{z}$ metod utrwalania $\mathrm{i}$ aplikacji bakterii, propagowaną $\mathrm{W}$ przemyśle spożywczym, medycynie, gospodarce ściekami, a także w rolnictwie (Yabur i wsp. 2007; Cook i wsp. 2012; Tripathi i Giri 2014). Pozytywne efekty zastosowania mikrogranul alginianowych jako sposobu utrwalania i formy aplikacyjnej dla bakterii działających korzystnie na wzrost roślin obserwowali także Bashan (1998), Bashan i Gonzales (1999) oraz Bashan i wsp. (2002). Jednak wyniki uzyskane w prezentowanych badaniach sugerują, że w przypadkach skażonego patogenami podłoża ta forma nośnika dla bakterii może nie być właściwa. Wyjaśnienie tego zjawiska wymaga dalszych badań.

$\mathrm{Na}$ etapie produkcji rozsady sałaty, nie tylko mikrokapsuły wykazywały niekorzystny wpływ na rozwój siewek. Jako „kontrolę chemiczną" w doświadczeniach użyto Zaprawę Nasienną T 75 DS/WS, zawierającą jako substancję czynną tiuram. Ten preparat hamował wzrost rozsady $\mathrm{w}$ porównaniu $\mathrm{z}$ kontrolą (tab. 1). Słabsze były wschody i masa roślin. Po przesadzeniu do gruntu sałata rosła gorzej, co w rezultacie było jednym z czynników obniżenia wielkości plonu (tab. 2). Zadaniem zapraw nasiennych jest ochrona roślin w początkowych fazach ich wzrostu. Jednak pewne doniesienia wskazują na potencjalny fitotoksyczny efekt niektórych zapraw chemicznych. W badaniach Orzeszko-Rywki i wsp. (2011) zaprawa Sanox 500 FS (karboksyna 21\% i tiuram 21\%) okazała się toksyczna dla nasion sałaty, pomimo przygotowania zgodnie z instrukcją na opakowaniu. Stosowanie tiuramu z karboksyną ograniczało również indeks wigoru i masę siewek łubinu żółtego (Faligowska i wsp. 2013), a zaprawy nasienne Funaben T, Sarfun T 450 FS i Super Homai 70 DS istotnie obniżały energię kiełkowania nasion koniczyny czerwonej (Ćwintal i Sowa 2010). W prezentowanej pracy, we wszystkich latach badań, rośliny sałaty traktowane Zaprawą Nasienną T 75 DS/WS były też istotnie silniej porażane przez patogeny niż rośliny w pozostałych obiektach. Indeks porażenia wskazuje, że sałata była o około $60 \%$ bardziej porażona niż rośliny kontrolne (tab. 2). Sprawcą chorób sałaty pod koniec wegetacji był głównie grzyb $S$. sclerotiorum, sprawca zgnilizny twardzikowej. W mniejszym stopniu występowała szara pleśń wywoływana przez Botrytis cinerea. Powodem większego porażenia roślin zaprawianych Zaprawą Nasienną T 75 DS/WS mogło być obniżanie naturalnej odporności sałaty w wyniku zastosowanego preparatu. Dias (2012) opisuje ograniczenie aktywności fotosyntetycznej u roślin traktowanych fungicydami, co wpływało negatywnie na produkcję ich biomasy i plonowanie. Jednak wyjaśnienie zjawiska większej podatności zaprawianej sałaty na choroby wymaga szczegółowych badań.

Zastosowane w fazie rozsady bakterie nie chroniły sałaty przed chorobami, ale też nie obserwowano działania negatywnego (tab. 2). Podlewanie rozsady zawiesiną bakterii, pomimo znacznej stymulacji wzrostu nie miało później istotnego wpływu na plon sałaty. Podobne rezultaty uzyskali Malkoclu i wsp. (2016) w uprawie sałaty ekologicznej. Natomiast ograniczenie wzrostu roślin w fazie rozsady, spowodowane użyciem mikrokapsuł alginianowych, skutkowało istotnym obniżeniem plonu, związanym ze zmniejszeniem masy główek. Pomimo braku pozytywnych efektów bakterii B125 i PZ9 na plon sałaty w polu, w literaturze można znaleźć informacje na temat dodatniego działania różnych bakterii na wzrost tych roślin (Sottero i wsp. 2006; Chamangasht i wsp. 2012).

$\mathrm{W}$ doświadczeniach z ogórkami zastosowano szczep bakterii E. cloacae sp. PT60. Stwierdzono, że zarówno podlewanie zawiesiną komórek bakterii, jak i użycie Zaprawy Nasiennej T 75 DS/WS nie miało istotnego wpływu na wschody ogórków (tab. 3). Jednak, podobnie jak w uprawie sałaty, zastosowanie mikrokapsuł alginianowych z PT60 istotnie obniżało wschody. Mogło to być związane ze stymulacją naturalnie występujących w glebie grzybów zgorzelowych.

Zastosowane zabiegi nie miały istotnego wpływu na plonowanie roślin ogórka (tab. 3). W obiektach podlewanych zawiesiną PT60 obserwowano jedynie tendencję do zwiększonego plonowania, tj. około $7-12 \%$. Z kolei

Tabela 1. Wpływ bakterii PZ9 i B125 na wschody sałaty i wzrost rozsady

Table 1. The effect of bacteria PZ9 and B125 on lettuce germination and transplants growth

\begin{tabular}{l|c|c|c}
\hline $\begin{array}{c}\text { Wariant } \\
\text { Treatment }\end{array}$ & $\begin{array}{c}\text { Wschody } \\
\text { Germination } \\
{[\%]}\end{array}$ & $\begin{array}{c}\text { Śzieża masa części nadziemnych } \\
\text { Shot fresh weight } \\
{[\mathrm{g}]}\end{array}$ & $\begin{array}{c}\text { Sucha masa korzeni } \\
\text { Root dry weight } \\
{[\mathrm{mg}]}\end{array}$ \\
\hline Kontrola - Control & $73,5 \mathrm{bc}$ & $6,42 \mathrm{a}$ & $82,0 \mathrm{~b}$ \\
\hline Tiuram - Thiram & $65,7 \mathrm{c}$ & $4,55 \mathrm{~b}$ & $77,3 \mathrm{~b}$ \\
\hline PZ9 + B125 zawiesina - suspension & $86,1 \mathrm{a}$ & $6,97 \mathrm{a}$ & $111,8 \mathrm{a}$ \\
\hline PZ9 + B125 kapsuły - capsules & $77,8 \mathrm{ab}$ & $3,39 \mathrm{c}$ & $75,0 \mathrm{~b}$ \\
\hline
\end{tabular}

Prezentowane wyniki stanowią średnią z doświadczeń prowadzonych w latach 2012-2015. Wartości przedstawione w kolumnach oznaczone tą samą literą nie różnią się istotnie według testu wielokrotnego rozstępu Duncana przy $\mathrm{p} \leq 0,05$

Data represent means of the results obtained in the experiments conducted in the years 2012-2015. Values in columns followed by the same letter are not significantly different according to Duncan multiple range test at $\mathrm{p} \leq 0.05$ 
Tabela 2. Wpływ mieszanki bakterii PZ9 i B125 na plonowanie i zdrowotność roślin sałaty kruchej w doświadczeniach polowych

Table 2. The effect bacterial mixture PZ9 and B125 on yield and health of iceberg lettuce in field experiments

\begin{tabular}{l|c|c}
\multicolumn{1}{c|}{$\begin{array}{c}\text { Wariant } \\
\text { Treatment }\end{array}$} & $\begin{array}{c}\text { Plon - Yield } \\
{\left[\mathrm{kg} / \mathrm{m}^{2}\right]}\end{array}$ & $\begin{array}{c}\text { Porażenie roślin (skala 0-4) } \\
\text { Diseases severity (index 0-4) }\end{array}$ \\
\hline Kontrola - Control & $2,04 \mathrm{a}$ & $1,89 \mathrm{~b}$ \\
\hline Tiuram - Thiram & $1,55 \mathrm{~b}$ & $3,10 \mathrm{a}$ \\
\hline PZ9 + B125 zawiesina - suspension & $1,76 \mathrm{ab}$ & $2,14 \mathrm{~b}$ \\
\hline PZ9 + B125 kapsuły - capsules & $1,13 \mathrm{c}$ & $1,90 \mathrm{~b}$ \\
\hline
\end{tabular}

Prezentowane wyniki stanowią średnią z doświadczeń prowadzonych w latach 2012-2015. Wartości przedstawione w kolumnach oznaczone tą samą literą nie różnią się istotnie według testu wielokrotnego rozstępu Duncana przy $\mathrm{p} \leq 0,05$

Data represent means of the results obtained in the experiments conducted in the years 2012-2015. Values in columns followed by the same letter are not significantly different according to Duncan multiple range test at $\mathrm{p} \leq 0.05$

Tabela 3. Wpływ różnych metod aplikacji bakterii PT60 na wschody ogórków, plonowanie i wystepowanie mączniaka rzekomego Table 3. The effect of different applications of bacteria PT60 on cucumber germination, yield and downy mildew intensity

\begin{tabular}{|c|c|c|c|c|c|c|}
\hline \multirow{3}{*}{$\begin{array}{l}\text { Wariant } \\
\text { Treatment }\end{array}$} & \multirow{3}{*}{$\begin{array}{c}\text { Wschody } \\
\text { Germination } \\
{[\%]}\end{array}$} & \multicolumn{4}{|c|}{ Plon - Yield [kg/m²] } & \multirow{3}{*}{$\begin{array}{c}\text { Mączniak rzekomy } \\
\text { Downy mildew } \\
{[\%]}\end{array}$} \\
\hline & & \multicolumn{4}{|c|}{ lata - years } & \\
\hline & & 2012 & 2013 & 2014 & 2015 & \\
\hline $\begin{array}{l}\text { Kontrola } \\
\text { Control }\end{array}$ & $84,5 \mathrm{a}$ & 4,72 & 0,90 & 3,02 & 0,68 & $12,2 \mathrm{a}$ \\
\hline $\begin{array}{l}\text { Tiuram } \\
\text { Thiram }\end{array}$ & $84,3 \mathrm{a}$ & - & 1,10 & 2,42 & 0,87 & $10,8 \mathrm{~b}$ \\
\hline $\begin{array}{l}\text { PT60 zawiesina } \\
\text { PT60 suspension }\end{array}$ & $80,3 \mathrm{a}$ & 5,05 & 0,98 & - & 0,76 & $8,4 \mathrm{c}$ \\
\hline $\begin{array}{l}\text { PT60 kapsuły } \\
\text { PT60 capsules }\end{array}$ & $49,5 \mathrm{~b}$ & - & 0,87 & 2,24 & 0,71 & $9,5 \mathrm{bc}$ \\
\hline
\end{tabular}

Wyniki prezentowane w kolumnach „,wschody” i „maczniak” stanowią średnią z doświadczeń prowadzonych w latach 2012-2015. W tabeli przedstawiono wartości drugiej oceny porażenia roślin, gdzie obserwowano istotne różnice pomiędzy wariantami. Porażenie obserwowane podczas wstępnej oceny mączniaka oraz ostatniej nie różniło się istotnie w poszczególnych obiektach. Wartości przedstawione w kolumnach oznaczone tą samą literą nie różnią się istotnie według testu wielokrotnego rozstepu Duncana przy $\mathrm{p}<0,05$. Plonowanie ogórków nie różniło się istotnie w kolejnych latach

Data in columns "germination" and "downy mildew" represent means of the results obtained in the experiments conducted in the years 2012-2015. In the table, values of second powdery mildew ratings are presented as significantly different. Severity of the pathogen infections observed in the first and last disease rating did not differ between tretaments. Values in a column followed by the same letter are not significantly different according to Duncan multiple range test at $\mathrm{p} \leq 0.05$. The yield of cucumber was not significantly different

w obiektach, gdzie zastosowano zaprawianie nasion mikrokapsułami, pomimo znacznie mniejszej obsady roślin, plon nie różnił się od tego uzyskanego z poletek kontrolnych. Prawdopodobnie rośliny, dysponując większą powierzchnią i lepszym dostępem światła przy ograniczonej obsadzie na poletku, mogły intensywniej owocować. Natomiast stosowanie bakterii PT60, niezależnie od metody aplikacji, istotnie ograniczało porażenie roślin ogórka przez mączniaka rzekomego wywoływanego przez $P$. cubensis (tab. 3). Najlepsze efekty uzyskiwano stosując podlewanie zawiesiną PT60, jednak zaprawianie nasion mikrokapsułami z tymi bakteriami również istotnie ograniczało mączniaka. Różnice porażenia występowały głównie na początku rozwoju choroby. W późniejszych etapach, przy większym nasileniu mączniaka, różnice zacierały się.

Wcześniejsze badania wskazują, że jednym $\mathrm{z}$ mechanizmów działania PT60 jest wzbudzanie odporności w roślinach (Szczech i Dyki 2007). W doświadczeniach Szczech i wsp. (2009) obserwowano silniejszą lignifikację korzeni pomidorów traktowanych PT60, zwiększenie grubości zdrewniałej tkanki ksylemu, a także wzrost zawartości fenoli (Szczech i wsp. 2009). Indukcja odporności w roślinach jest jednym z głównych mechanizmów działania bakterii wykazujących właściwości ochronne wobec chorób roślin (Bishnoi 2015). Wei i wsp. (1996) wykazali, że badane przez nich bakterie PGPR, stosowane na nasiona, wzbudzały odporność w roślinach ogórka, które były mniej podatne na choroby wywoływane przez grzyb Colletotrichum orbiculare lub bakterie Pseudomonas syringae pv. lachrymans. Podobne wyniki uzyskali El-Borollosy i Oraby (2012) wobec chorób wirusowych ogórka. W przedstawionych doświadczeniach ograniczenie mączniaka po zastosowaniu PT60 obserwowano szczególnie w początkowym okresie, kiedy nasilenie choroby było mniejsze. Pod koniec wegetacji rośliny we wszystkich obiektach były silnie porażane i w rezultacie nie uzyskano statystycznie istotnych różnic w plonowaniu. Jednak stabilność uzyskiwanych w warunkach polowych wyników wskazuje na możliwość stosowania bakterii PT60 w integrowanej ochronie ogórka, np. w połączeniu z ochroną chemiczną i innymi zabiegami agrotechnicznymi.

\section{Wnioski / Conclusions}

1. Podlewanie mieszanką bakterii B125 + PZ9 powodowało istotną poprawę wschodów i stymulację wzrostu 
rozsady sałaty, która była silniejsza i lepiej ukorzeniona niż rośliny nietraktowane.

2. W doświadczeniach $\mathrm{z}$ sałatą kruchą stwierdzono niekorzystny wpływ stosowania Zaprawy Nasiennej T 75 DS/WS, która pogarszała wzrost rozsady, a w warunkach silnej presji patogenów w uprawie polowej, powodowała większą wrażliwość roślin na choroby.
3. Stosowanie bakterii $\mathrm{w}$ mikrokapsułach alginianowych może wpływać niekorzystnie na wschody i wzrost roślin w początkowych etapach rozwoju.

4. Bakterie PT60 w uprawie ogórka gruntowego istotnie ograniczały występowanie mączniaka rzekomego w początkowym okresie rozwoju choroby.

\section{Literatura / References}

Ali G.S., Norman D., El-Sayed A.S. 2015. Soluble and volatile metabolites of plant growth-promoting rhizobacteria (PGPRs): role and practical applications in inhibiting pathogens and activating induced systemic resistance (ISR). Advances in Botanical Research 75: $241-284$.

Bashan Y. 1998. Inoculants of plant growth-promoting bacteria for use in agriculture. Biotechnology Advances 16: 729-770.

Bashan Y., Gonzales L.E. 1999. Long-term survival of the plant growth-promoting bacteria Azospirillum brasilense and Pseudomonas fluorescens in dry alginate inoculant. Applied Microbiology and Biotechnology 51: 262-266.

Bashan Y., Hernandez J.P., Leyva-Macario Bacilio L.A. 2002. Alginate microbeads as inoculant carriers for plant growth-promoting bacteria. Biology and Fertility of Soils 35: 359-368.

Bhattacharyya P.N., Jha D.K. 2012. Plant growth-promoting rhizobacteria (PGPR): emergence in agriculture. World Journal of Microbiological Biotechnology 28: 1327-1350.

Bishnoi U. 2015. PGPR interaction: an ecofriendly approach promoting the sustainable agriculture system. Advances in Botanical Research 75: 81-113.

Chamangasht S., Ardakami M.R., Khavazi K., Abbaszadeh B., Mafakheri S. 2012. Improving lettuce (Lactuca sativa L.) growth and yield by the application of biofertilizers. Annals of Biological Research 3 (4): 1876-1879.

Cook M.T., Tzortzis G., Charalampopoulos D., Khutryanskiy V.V. 2012. Microencapsulation of probiotics for gastrointestinal delivery. Journal of Controlled Release 162 (1): 56-67.

Ćwintal M., Sowa P. 2010. Wpływ zapraw nasiennych i stymulacji laserowej na kiełkowanie nasion koniczyny czerwonej. Annales Universitas Mariae Curie-Skłodowska, Lublin - Polonia LXV (3): 1-9.

Dias M.C. 2012. Phytotoxicity: An overview of the physiological responses of plants exposed to fungicides. Journal of Botany 2012: 1-4.

El-Borollosy A.M., Oraby M.M. 2012. Induced systemic resistance against Cucumber mosaic cucumovirus and promotion of cucumber growth by some plant growth-promoting rhizobacteria. Annals of Agricultural Science 57 (2): 91-97.

Faligowska A., Panasiewicz K., Szymańska G., Bartos-Spychała M. 2013. Jakość siewna nasion łubinu żółtego w zależności od wybranych czynników agrotechnicznych. [The seeds quality of yellow lupine depending on selected agrotechnical factors]. Progress in Plant Protection/Postępy w Ochronie Roślin 53 (2): 293-296.

Hellriegel H., Wilfarth H. 1888. Untersuchungen über die Stickstoffnahrung der Gramineen und Leguminosen. Beilageheft zu der Zeitschrift des Vereins für Rubenzucker-Industrie Deutschen Reichs, 234 pp.

Howell C.R. 2003. Mechanisms employed by Trichoderma species in the biological control of plant diseases: the history and evolution of current concepts. Plant Disease 87: 4-10.

Malkoclu M.C., Tuzel Y., Ozaktan G.B., Yolageldi L. 2016. Effects of plant growth-promoting rhizobacteria on organic lettuce production. Proceedings of 3rd International Symposium on Organic Greenhouse Horticulture. Turkey, Izmir, April 11-14, 2016 , p. 74.

Orzeszko-Rywka A., Rochalska M., Balcer E. 2011. Przydatność czosnku, rumianku i nagietka do zaprawiania nasion warzyw. Journal of Research and Applications in Agricultural Engineering 56 (4): 52-57.

Ruzzi M., Aroca R. 2015. Plant growth-promoting rhizobacteria act as biostimulants in horticulture. Scientia Horticulturae 196: 124-134.

Sottero A.N., dos Santos Freitas S., Tavares de Melo A.M., Trani P.E. 2006. Rhizobacteria and lettuce: root colonization, plant growth promotion and biological control. Brazilian Journal of Soil Science 30 (2): 225-234.

Szczech M. 2009. Biologiczna ochrona roślin warzywnych przy użyciu mieszanek aktywnych mikroorganizmów. Raport no 2P06R08430. Instytut Warzywnictwa, Skierniewice, $35 \mathrm{ss}$.

Szczech M., Dyki B. 2007. Combination of microbial biocontrol agents to control rhizoctonia damping-off and fusarium wilt of tomato. IOBC-WPRS Bulletin 30 (6): 415-418.

Szczech M., Dyśko J. 2008. The possibility to use selected mixtures of PGPR bacteria in tomato cultivation. Vegetable Crops Research Bulletin 68: 47-56.

Szczech M., Kowalska B., Dyki B., Horbowicz M., Kowalczyk W. 2009. Microbial mixtures enhancing plant resistance to pathogen stress. IOBC-WPRS Bulletin 43: 89-94.

Szczech M., Maciorowski R. 2016. Microencapsulation technique with organic additives for microbial agents. Journal of Horticultural Research 24 (1): 111-122.

Tripathi M.K., Giri S.K. 2014. Probiotic functional foods: Survival of probiotics during processing and storage. Journal of Functional Foods 9: 225-241.

Verbon E.H., Liberman L.M. 2016. Beneficial microbes affect endogenous mechanisms controlling root development. Trends in Plant Science 21 (3): 218-229.

Wei G., Kloepper J.W., Tuzun S. 1996. Induced systemic resistance to cucumber diseases and increased plant growth by plant growth-promoting rhizobacteria under field conditions. Phytopathology 86 (2): 221-224.

Winder R.S., Wheeler J.J., Conder N., Otvos I.S., Nevill R., Duan L. 2003. Microencapsulation: a strategy for formulation of inoculum. Biocontrol Science and Technology 13: 155-169.

Yabur R., Bashan Y., Hernández-Carmona G. 2007. Alginate from the macroalgae Sargassum sinicola as a novel source for microbial immobilization material in wastewater treatment and plant growth promotion. Journal of Applied Phycology 19: 43-53. 